\title{
Factors Affecting Entrepreneurial Capacity Building of Smallholder Coffee Farmers in East Java Province
}

\author{
Sudarko $^{1^{*}}$, Sumardjo ${ }^{2)}$, Anna Fatchiya ${ }^{2}$, and Prabowo Tjitropranoto ${ }^{2)}$ \\ ${ }^{1)}$ Study Program of Agricultural Extension, Faculty of Agriculture, University of Jember, Indonesia \\ ${ }^{2}$ Faculty of Human Ecology, IPB University, Bogor, Indonesia \\ ${ }^{*}$ Corresponding author: sudarko8@ gmail.com \\ Received : 27 December 2019 / Accepted : 4 February 2020
}

\begin{abstract}
The income of smallholder coffee farmers can be increased by optimizing the added value of the product through increased entrepreneurial capacity. Coffee farmers need to adopt innovations and new approaches that are more sustainable with organic farming systems. East Java region is the largest coffee producer in Java island, fourth in Indonesia, and has an important contribution in coffee exports which is $24.4 \%$ of the national coffee export. The purpose of this study were to identify differences in characteristics, support of government extension services, private extension agents, and environmental support for smallholder coffee farmers and to analyze the effect of characteristics, government extension services, private extension agents, and environmental support on the entrepreneurial capacity of smallholder coffee farmers. This study were carried out at Arabica coffee farms in Bondowoso Regency and Robusta coffee farms in Malang Regency, East Java from August to October 2019. The survey method was used in this research. Data were collected through interviews with questionnaires in a total of 376 smallholder coffee farmers. Data were analyzed using descriptive (SPSS) and inferential statistics (structural equation model/SEM analysis using Smart PLS). The results of research showed that non formal education and roles of private extension agents were found to be low. This low value of non-formal education attended by farmer was affected by the low intensity of training program, field school, and courses for farmers. Moreover, motivation, government extension support, environmental support, and entrepreneurial capacity of smallholder coffee farmers were categorized as moderate. Factors significantly influenced entrepreneurial capacity of coffee farmers included: characteristics of farmers, government extension support, roles of private extension agents, and environmental support. The role of government to strengthen private extension agents was possible through partnership between coffee farmers, government and exporter or private sectors. The motivation in business development, the use of conventional mass media by smallholder coffee farmers and the role of motivators of private extension workers for coffee farmers in Bondowoso regency were higher than in Malang regency.
\end{abstract}

Keywords: Entrepreneurial capacity, smallholders coffee farmers, private extension agents 


\section{INTRODUCTION}

As a commodity, coffee beens has a great economic potential. This becomes a business opportunity for smallholder coffee farmers in developing a diversified business based on coffee products. However, the development of conventional coffee business faced many problems such as traditional processing, low business scale, and low income due to low quality and productivity (Aklimawati et al., 2015a; Hafif et al., 2014). Organic coffee farming system as an innovation for farmers also deals many problems concerning the adoption process, low productivity, and the issues of structural coordination with related stakeholders also the situation in which smallholder coffee farmers face difficulty to penetrate the potential market. According to Hawkins \& van Den Ban (1999), it is better for smallholder coffee farmer, as an individual, to be participatively directed concerning the decision to apply new innovation or technology such as organic agriculture. Coffee plantation absorbed a total of 1.79 million labors as farmers with production of 639,305 ton, yet the majority of entrepreneurial capacity of coffee farmer was still low (Hartatri et al., 2016; Ditjenbun, 2016).

National data of entrepreneurship index in Indonesia of $3.1 \%$ was far behind that of developed country that reached $14 \%$ (Kemen KUKM, 2018). In fact, about $80 \%$ of total smallholder coffee production was traded in the form of raw beans and parchment dried coffee, thus only $20 \%$ of the production was further processed, causing non-optimal economic value added (Widyotomo et al., 2012; Aklimawati et al., 2015b). Smallholder coffee farmers should be immediately supported and strengthened for their entrepreneurial capacity to be able to improve their product quality and diversify coffee processingbased products which will increase sale value and value added and further results in profit and business sustainability. In general, business scale of smallholder coffee farmer was still inefficient since the national average farming area was less than 1 hectare per the head of farming household (ideally it is $2.7 \mathrm{ha}$ ), resulting fundamental problem in the development of coffee agribusiness in Indonesia (Hartatri et al., 2016).

Darmadji (2012) reported that entrepreneurial capacity of farmers that was measured from the aspect of need for achievement, risk acceptance, independence, creativity, confidence, knowledge, skill, and market orientation were included in high category. Farmer entrepreneurship is one of strategic needs in the management of many microbusiness in rural area. Some of these various determining factors are internal and the others are external (Dumasari, 2014). Mukti et al. (2018) mentioned that farmer transformation into entrepreneur has been an unavoidable demand to continue business. Furthermore, Ningsih (2014) found that entrepreneurial skill with good criteria at the level of rural farmer was easier to be learnt and done jointly in agricultural institution, such as association of farmer group (gapoktan) or farmer group (poktan). Nurdiani (2013) revealed that entrepreneurship level of farmer was already high. Factors of individual, physical, social, economic, and institutional environment positively and significantly affected entrepreneurship of farmer and farming performance. Thus, it is required to conduct study that measures entrepreneurial capacity of sustainable smallholder coffee farmers including internal and external factors that influence it.

Coffee is one of the commodities of plantation products which has an important role in economic activities in East Java. Coffee is also one of Indonesia's important export commodities as a source of foreign exchange besides oil and gas. Coffee is the third leading commodity in East Java after sugar cane and 
tobacco. BPS (2018) also reported coffee area in East Java is 106,545 ha and production of 64,804 tons, the fourth national producer with productivity of 0.803 tons/ha/year above the national average of 0.773 tons/ha/year, and the amount of coffee exports of 68,285 tons (24.4\% of national exports). Coffee consumption level per capita is $0.55 \mathrm{~kg} / \mathrm{year} /$ person, so that East Java coffee needs approximately 20,900 tons. Besides that, coffee commodity has become a part of community life in East Java because the coffee plant has been cultivated by farmers since the $17^{\text {th }}$ century colonial era which is famous for Javanese coffee, such as Ijen-Raung, Blawan, Dampit and BromoTengger coffee.

Basically, smallholder coffee farmers has already had entrepreneurial spirit (Aklimawati et al., 2015b). Hence, it is necessary to investigate internal and external factors that affect entrepreneurial capacity of smallholder coffee farmers. Therefore, the objectives of this study are: to analyze characteristic level of coffee farmers, government extension support, private extension agents, environmental support, and entrepreneurial capacity level of smallholder coffee farmers and to analyze factors that determine entrepreneurial capacity building of smallholder coffee farmers.

\section{MATERIALS AND METHODS}

This study applied the method of survey supported by qualitative data. The location of this research conducted is East Java. East Java region is the largest coffee producer in Java and fourth in Indonesia. In addition, coffee is a leading commodity for foreign exchange earning, contributing to East Java coffee exports accounting for $24.4 \%$ of national coffee exports (BPS, 2018). East Java is also a specialty coffee producer so that there is recognition of geographical indications (IG) and global certificates. Research was conducted during
August-October 2019 in locations purposively determined, namely Malang Regency and Bondowoso Regency of East Java Province with consideration of smallholder coffee development center according to the Decision of the Minister of Agriculture No. 830 in 2016 about the establishment of national agricultural region. Bondowoso Regency was selected as the representative of area producing Arabica coffee with high altitude, while Malang regency represented Robusta coffee with moderate altitude.

Population in this study was all coffee farmers joined farmer group in the center of coffee producing area in the Regency of Malang and Bondowoso. The total population in research was reached 6,470 people, consisted of 917 people from Bondowoso Regency (Distan Bondowoso, 2018) and 5,553 people from Malang Regency (Distan Malang, 2018). Determination of sample number was done using the formula of Slovin with margin of error of five percent (Arikunto, 2010), resulted in 376 respondents. The respondents consisted of 76 coffee farmers from smallholder coffee center in Bondowoso (District of Sumberwringin, Sempol, Sukosari, Maesan, and Pakem) and 300 smallholder coffee farmers in Malang (District of Dampit, Tirtoyudo, Sumbermanjing, Ampelgading, Wonosari, and Poncokusuma). Sample of respondent was determined through the technic of purposive and proportional cluster random sampling (Arikunto, 2010; Saragih, 2018). This study used quantitative and qualitative data obtained through observation and interview. Qualitative data were collected via depth-interview and group discussion involving related parties such as the head of Agriculture Services, agricultural extension workers, the leader of farmer group, coffee trader, advanced farmers, Regional Infrastructure Development Agency (Bappeda), and other coffee stakeholders. 
Variables of farmer characteristic (nonformal education and business motivation), government extension support, self-help and private extension workers, environmental support, and entrepreneurial capacity of coffee farmers were measured using the score approach of Likert (Sugiyono, 2012) with scale range (1-4). Measurement was based on coffee farmers' perceptions of certain standards on a number of questions with answer choices score 1: don't know, score 2: disagree, score 3: quite agree and score 4: agree. Moreover, dependent variable of entrepreneurial capacity of coffee farmers was determined using the approach/ adaptation of McCleland concept (Pambudy \& Priatna, 2017). Mitchelmore \& Rowley (2013) and Hisrich et al. (2017) mentioned that entrepreneurial capacity can be measured for individual with main indicator of personal competence, management and business competence, and technical competence.

This research used construct and content validity with analysis of product-moment correlation based on Karl Pearson (Arikunto, 2010). According to Sugiyono (2017), if the coefficient of correlation $\geq 0.3$ thus instrument items are considered valid. This study also applied Cronbach's Alpha reliability test (Jogiyanto, 2014) by testing instrument to coffee farmers with similar characteristics to respondents in July 2019, those were 30 members of coffee farmer group Sidomulyo 1 in Sidomulyo Village Silo District Jember Regency East Java. Furthermore, coefficients of correlation of product-moment for variable of farmer characteristic were (0.601-0.855), extension support were (0.396-0.872), environmental support were (0.364-0.832), and entrepreneurial capacity were (0.393-0.948), respectively, indicated that instrument was valid. Moreover, Cronbach's Alpha reliability test resulted in value of farmer characteristic of 0.840 , extension support of 0.683 , environmental support of 0.503 , and entrepreneurial capacity of 0.850 which means that instrument of variables was reliable for research data collection.

Data analysis was done according to each research objective. The first objective was to analyze the difference of coffee farmers' characteristics also government extension support, private extension, and environmental support as well as the level of entrepreneurial capacity of smallholder coffee farmer was investigated using descriptive analysis (Excel and SPSS PASW program). The second objective was to determine factors affecting entrepreneurial capacity of smallholder coffee farmers was examined by performing the analysis of Structural Equation Model (SEM) with Smart Partial Least Square (PLS).

\section{RESULTS AND DISCUSSION}

\section{Factors Affecting Entrepreneurial Capacity}

Based on Table 1, it is known that nonformal education of coffee farmer obtained low category. Non-formal education is the frequency of farmers to participate in school (of no structure and level) such as training, field school, and comparative study related to coffee farming within the past year. Result of interview with farmers showed that the number of participants in such training and similar activity was still limited and only the leader of farmer group or public figures often participated in the activity as representative, yet not all farmers had equal opportunity. To increase the capacity of smallholder coffee farmers, more education and training of coffee innovation from various parties are required, both from the government and non-government. Novanda (2019) mentioned that entrepreneurial capacity of farmer could be strongly affected by the existence of farmer institution such as farmer group and the association of farmer group (gapoktan) 
that are active as the learning media for the member.

Motivation of coffee farmer in business development was categorized as moderate. Motivation of coffee farmer was measured through the aspects of willingness to expand farming land, increase in capital, quality and diversification, marketing expansion, and certification. The field data indicated that the majority of coffee farmers were willing to increase their profit and quality of product (high category), while other aspects were categorized as low and moderate. It is possible to strengthen the motivation of coffee farmers by providing the evidence of profit gained from innovation, particularly economic and social profit. Converesely, Leilida et al. (2014) found that motivation of smallholder coffee farmers was in high category.

Government extension support for smallholder coffee farmer was categorized as moderate (Table 1). The activity of extension was measured through aspects of extension workers who actively participated in meeting, frequency of extension officer to visit coffee plantation, frequency of extension officer to visit farmers' house, extension officers take farmers out of the village to obtain knowledge or new insight, and preparation of extension workers to meet coffee farmers' need. Concerning the field data, perception of farmer on government extension officers was included in high category related to the aspect of the presence in group meeting, while other aspects were into moderate category. Group meeting was regularly held once in a month or adjusted to the needs of smallholder coffee farmers.

Table 1 shows that the role of private extension workers for coffee farmers was still low. Based in the result of interview with farmers, private extension agents were provided by exporters or large traders and often became facilitator, mediator, even motivator to produce high quality coffee to be further purchased at certain price. In Bondowoso, private extension workers were from coffee company/buyer and exporter, such as PT. Indokom Citra Persada, PT. Sari Makmur, PT. Sunda Mountain, PT. Olam Sunda Hijau and other trading business such as individual traders, cafe owners. Moreover, private extension agents in Malang were from CV. Asal Jaya that provided foreign expert for coffee training and certification.

Table 1 shows that the motivation in business development, the use of conventional mass media by smallholder coffee farmers and the role of motivators of private extension workers for coffee farmers in Bondowoso regency were higher than in Malang regency. This condition occurs due to the Bondowoso regency government making coffee commodities as a superior product for regional economic development so that it is intensive in empowering smallholder coffee farmers.

Environmental support in term of ecological aspect according to smallholder coffee farmer perception was categorized as high (Table 1). Result of interview with farmers and other key informants showed the perception of coffee farmers that has started to apply organic farming system. They felt that during certain period after land conversion (2-3 years), ecological condition concerning soil fertility, water source, and rainfall was found to be good, yet it has not completely followed the strict standard of organic farming system. Smallholder coffee farmer has started to realize to maintain environmental sustainability by minimizing the use of chemical inputs and meeting the standard operational procedure of good agricultural practices (GAP).

The aspect of conventional mass media use for coffee farming business development such as the use of television, radio, newspaper, magazine, leaflet or brochure was included 
in moderate category (Table 1). The field data showed that the mass media frequently used by coffee farmers were television, radio, newspaper, magazine, and leaflet/brochure, respectively, since there was only small segment about coffee in those mass media, thus it was hard for farmers to access or obtain information. However, the use of conventional mass media is still relevant in the future as communication media for the development of smallholder coffee farmers. In reality, the ability of farmers to operate information technology-based communication media were weak because the average age of coffee farmers were old, formal education was low, and generally digital literacy were also a low category.

According to Table 1, it is known that entrepreneurial capacity of smallholder coffee farmer was categorized as moderate. The aspect of confidence and risk acceptance was included in high category, while the aspect of determination to succeed, anticipation for future, innovative and creative, and ability to establish cooperation belonged to moderate category. This finding was based on the situation that coffee plants have been cultivated over generations for quite a long time, thus the price and production often fluctuate. Yet, farmers were still enthusiastic with the hope that their coffee farming business remains the mainstay of family economy. However, paternalistic attitude of government towards agricultural sector concerning the development of agriculture in Indonesia obviously hindered farmers' motivation to have entrepreneurial attitude (Mukti et al., 2018). It is possible to increase entrepreneurial capacity through individualistic approach to coffee farmers, namely by strengthen their mental attitude and skill/ability. According to Zizile \& Tendai (2018), entrepreneurial capacity might affect the performance and how farmers

Table 1. Descriptive result of factors affecting entrepreneurial capacity of smallholder coffee farmer in the Regency of Bondowoso and Malang, East Java Province in 2019

\begin{tabular}{|c|c|c|c|c|c|c|}
\hline Factors & $\begin{array}{l}\text { Average total } \\
\text { score }(n=76) \\
\text { in Bondowoso }\end{array}$ & Category & $\begin{array}{l}\text { Average total } \\
\text { score }(\mathrm{n}=300) \\
\text { in Malang }\end{array}$ & Category & $\begin{array}{c}\text { Average total } \\
\text { score }(n=376 \\
\text { coffee farmers })\end{array}$ & Category \\
\hline \multicolumn{7}{|l|}{$\begin{array}{l}\text { Characteristics of } \\
\text { Coffee Farmer }\end{array}$} \\
\hline $\begin{array}{l}\text { - Non-formal education } \\
\text { (times) }\end{array}$ & 10.09 & Low & 13.44 & Low & 12.77 & Low \\
\hline $\begin{array}{l}\text { - Motivation of business } \\
\text { development (score) }\end{array}$ & 70.54 & High & 57.91 & Moderate & 60.46 & Moderate \\
\hline $\begin{array}{l}\text { Government Extension } \\
\text { Support (score) }\end{array}$ & 51.21 & Moderate & 39.03 & Moderate & 41.49 & Moderate \\
\hline - Extension Activity & 65.26 & Moderate & 49.73 & Moderate & 52.87 & Moderate \\
\hline $\begin{array}{l}\text { - Appropriateness of } \\
\text { extension material }\end{array}$ & 37.16 & Moderate & 28.32 & Low & 30.11 & Low \\
\hline $\begin{array}{l}\text { Private Extension } \\
\text { Support (score) }\end{array}$ & 23.90 & Low & 25.72 & Low & 25.35 & Low \\
\hline - The role of facilitator & 23.68 & Low & 24.61 & Low & 24.42 & Low \\
\hline - The role of motivator & 21.49 & Low & 26.06 & Low & 25.13 & Low \\
\hline - The role of mediator & 26.54 & Low & 26.50 & Low & 26.51 & Low \\
\hline $\begin{array}{l}\text { Environmental } \\
\text { Support (score) }\end{array}$ & 54.14 & Moderate & 44.95 & Moderate & 46.81 & Moderate \\
\hline - Ecological suitability & 87.57 & High & 79.74 & High & 81.32 & High \\
\hline - Conventional mass media & 20.70 & Low & 10.16 & Low & 12.29 & Low \\
\hline $\begin{array}{l}\text { Entrepreneurial Capacity } \\
\text { of Farmer (score) }\end{array}$ & 68.16 & Moderate & 67.67 & Moderate & 67.77 & Moderate \\
\hline - Determination to succeed & 79.82 & High & 79.81 & High & 79.81 & High \\
\hline - Anticipation for future & 67.63 & Moderate & 65.78 & Moderate & 66.15 & Moderate \\
\hline - Confidence & 81.84 & High & 80.73 & High & 80.96 & High \\
\hline - Risk acceptance & 64.39 & Moderate & 73.27 & High & 71.47 & High \\
\hline - Innovative and creative & 43.77 & Moderate & 43.04 & Moderate & 43.19 & Moderate \\
\hline - Ability to cooperate & 71.49 & High & 63.40 & Moderate & 65.04 & Moderate \\
\hline
\end{tabular}


tolerate changes by developing innovative idea, opportunity, and risk of business.

\section{Factors Affecting Entrepreneurial Capacity}

According to Figure 1, namely the fit model and evaluation of SEM structural measurement through the analysis of fitted partial least square (PLS), it was found that factors affecting entrepreneurial capacity of smallholder coffee farmers included characteristics, government extension support, private extension, and environmental support. The latent variable of environmental support was found to have the greatest effect among the other latent variables. Based on Figure 1, it was also concluded that measurement model that formed the latent variables (outer model) and path coefficient (inner model) are explained in Table 2.

Structural equation of factors $(\mathrm{X})$ affecting entrepreneurial capacity of smallholder coffee farmers $(\mathrm{Y})$ is written as follows:

$$
\mathrm{Y}=0.292 \mathrm{X} 1+0.167 \mathrm{X} 2+0.186 \mathrm{X} 3
$$

$+0.287 \mathrm{X} 4 \quad \mathrm{R}^{2}=0.43$ (Moderate)

The $\mathrm{R}^{2}$ value of 0.43 was categorized as moderate, which means that structural model could explain $43 \%$ of the data variance in the form of variables, while the rest of $57 \%$ was affected by other variables that were not included in the model. Following the result of field observation and interviews, other variables that also influenced entrepreneurial capacity of smallholder coffee farmer were variable of agribusiness capacity of smallholder coffee farmers, availability of business capital, demand quantity, and the price of secondary and tertiary products of coffee, yet those variables were not specifically analyzed in this study.

Table 2 shows that the variable of farmer characteristics formed by the indicator of non-formal education and business motivation significantly affected entrepreneurial capacity of farmers. More non-formal education attended will result in better entrepreneurial capacity of smallholder coffee farmers. This situation is in accordance with the result of study conducted by Wibowo et al. (2012) and Pratita et al. (2018) that entrepreneurial capacity was influenced by education level, training, communication facility, and extension. Result of interview with the leader of farmer group indicated that coffee farmers have already had spirit to participate in training and seminars despite the limited opportunity. Motivation of coffee farmer to develop business significantly affected entrepreneurial capacity of farmer. This finding is similar to the outcome found by Pambudy \& Priatna (2017) that entrepreneurial behavior of farmer was determined by farmers' attitude, mental ability, and skill/ ability. Motivation as a positive mental attitude will encourage farmers to perform action towards more sustainable smallholder coffee business development. Managanta et al. (2019) also reported that motivation in business development also affected farmers' capacity. Entrepreneurial capacity of coffee farmers is closely related to the ability and characteristics of farmers. Therefore, maximizing the farmers' potency or strength along with local resource potential for product diversification becomes an important alternative to strengthen entrepreneurial capacity of

Table 2. The effect of exogenous latent variable on endogenous entrepreneurial capacity of smallholder coffee farmers in East Java, 2019

\begin{tabular}{lcccc}
\hline $\begin{array}{l}\text { Correlation of latent variables } \\
\text { with entrepreneurial capacity }\end{array}$ & $\begin{array}{c}\text { Path } \\
\text { coefficients }\end{array}$ & $\begin{array}{c}\text { t-Statistics } \\
\text { t-table }\end{array}$ & $\begin{array}{c}\text { Cut off } \\
(\alpha=5 \%), \\
(1,96)\end{array}$ & $\begin{array}{c}\text { Notes } \\
\text { (Significance) }\end{array}$ \\
\hline Characteristics of farmer & $0.292^{*}$ & 5.442 & $\geq 1.96$ & Significance \\
Government extension support & $0.167^{*}$ & 3.788 & $\geq 1.96$ & Significance \\
Private extension support & $0.186^{*}$ & 4.749 & $\geq 1.96$ & Significance \\
Environmental support & $0.297^{*}$ & 7.993 & $\geq 1.96$ & Significance \\
\hline
\end{tabular}




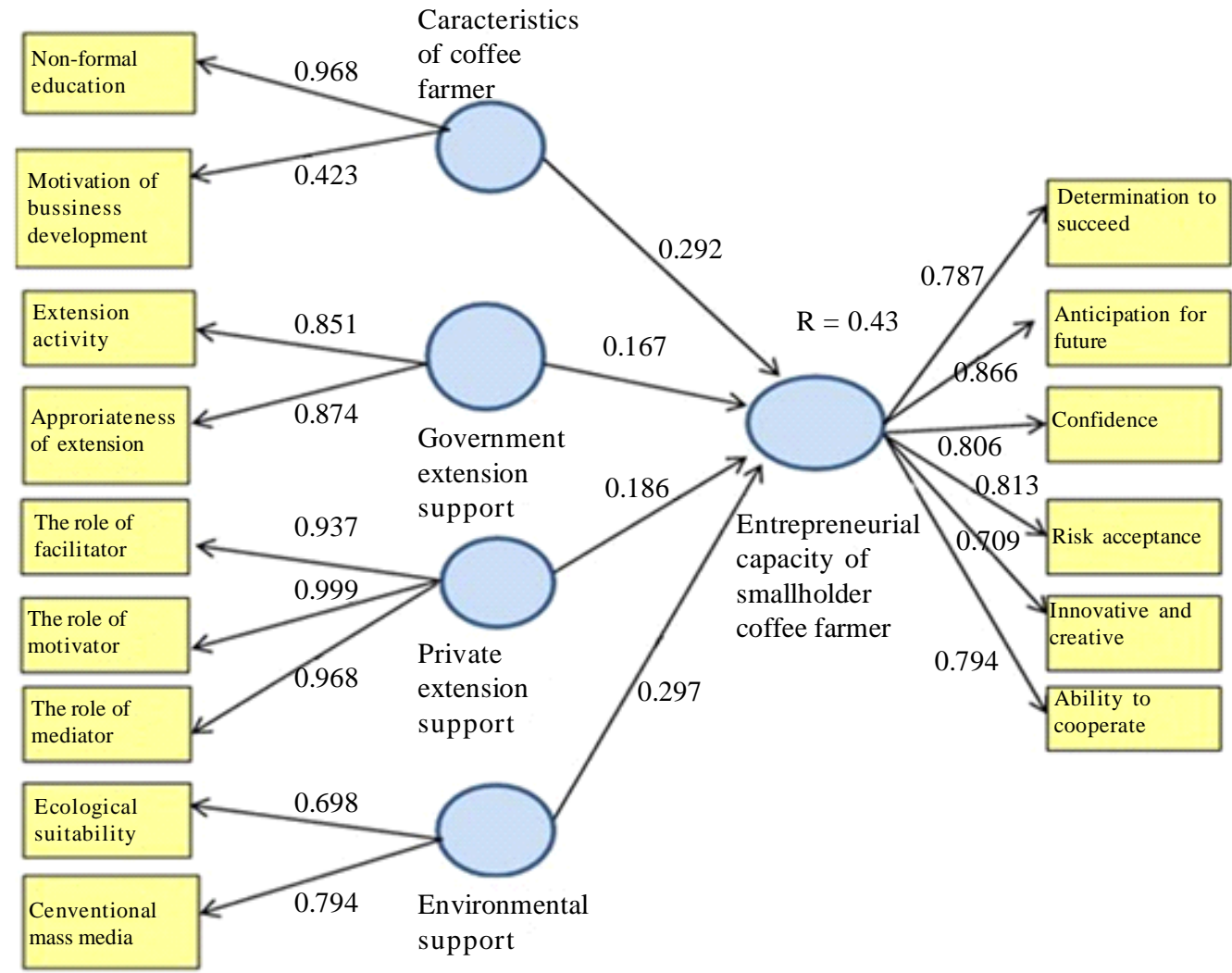

Figure 1. Partial least square model of factors affecting entrepreneurial capacity of smallholder coffee farmer in East Java

low-scale farmer (Budiningsih \& Watemin, 2014).

Variable of extension support that was measured through the indicator of extension activity and appropriateness of extension material also significantly affected entrepreneurial capacity. Result of interview and field data showed that only $6 \%$ of extension material met farmers' need, the rest was considered less and not appropriate, indicating that material appropriateness is required to be improved to meet the needs of coffee farmers. Organic coffee farmers highly need extension material about the production of organic fertilizer from coffee waste and manure, technic to produce disease and pest controlling material from natural ingredients, secondary and tertiary processing of coffee, and material concerning coffee certification as well as marketing strategy based on information technology. Therefore, coffee farmers should be proactive and independently find appropriate materials by joining the processing (UPH) and cooperate in a group (Aklimawati, 2017).

Variable of private extension support that was measured from the indicator of the role of extension worker as facilitator, motivator, and mediator significantly affected entrepreneurial capacity. This finding is in accordance with the result of study conducted by Suryanti et al. (2019) that the capacity of cattle farmers was influenced by the role of private extension agents, either the role as facilitator, dynamisator, educator, and motivator. The result of interview with farmer emphasized that the role of private extension officer should be clear 
and under the coordination of government extension worker to achieve synergy and obtain farmer's trust besides creating continuous social interaction. According to farmers, private extension agents must have economic motive such as selling fertilizer, products for pests of coffee plants such as herbicides and pesticides, and connecting farmers with buyers and both national and international coffee exporters. The strategic and typical position of private extension workers requires regulation and guidance concerning the rules and management of extension activity in order to strengthen farmer attitude to be strong and reliable agrientrepreneur. Mukti et al. (2018) found the fact that farmers still semicommercially performed their business, thus the quality of commodity was below the standard and not yet meeting the demand or market preference.

Moreover, variable of environmental support (from the indicator of ecological suitability and conventional mass media) significantly affected entrepreneurial capacity (Table 1). Coffee is a product closely related to the condition of nature and environment. Coffee with premium quality and specialty coffee must be produced from the environment that is suitable for coffee planting. Several places such as Bondowoso, around the slope of Mount Ijen-Raung (elevation of Ijen \pm 2,386 $\mathrm{m}$ above sea level and Raung $\pm 3,287$ $\mathrm{m}$ asl.) have already obtained the Geographical Indication (GI) certification, indicating that coffee in this area has comparative and competitive advantages for its quality and uniqueness/authenticity. This condition is confirmed by the finding of Hafif et al. (2014) that coffee plantation in Indonesia is mostly located in such a typical and diverse ecological environment, resulting in great potential to be developed.

In fact, mass media significantly affected entrepreneurial capacity of smallholder coffee farmers despite its low role. Thus, it is necessary to improve the role of mass media as media for development. This finding is in accordance with the result of study performed by Listiana et al. (2018) and Kilmanun \& Serom (2018) that the role of communication media was highly important for technological transfer acceleration in extension process in order to increase entrepreneurial capacity of farmers and extension workers. Based on the result of interview with farmers, it was found that farmers basically preferred television and radio to smartphone based media or other print media. However, farmers also thought that segment that discussed coffee business was still limited since entertainment segment dominated mass media. The phenomena confirmed the result of study carried out by Wibowo et al. (2012) that most farmers in Indonesia were not yet having entrepreneurial spirit. Hence, all related parties should introduce entrepreneurship to farmers in order to develop dynamic thoughts and action, being a risk taker and confidence, produce new products with value added, create employment or new jobs, and beneficial to other people. Considering that coffee is global commodity that requires processing and creativity in its service, Meredith \& Geoffrey $(1996,2000)$ mentioned that entrepreneurship is not only a practical knowledge, but more to a life style and certain principles that will affect business performance.

\section{CONCLUSIONS}

The level of characteristic of non-formal education of smallholder farmers and private extension support was found to be low. This low value of non-formal education attended by farmer was affected by the low intensity of training programs, field schools, and courses for farmers. The level of farmer motivation in business development was high. The level of government extension support, environmental support, and entrepreneurial 
capacity of smallholder coffee farmer were in the moderate category. Weak support from government and private extension for smallholder coffee plantation was influenced by the low roles of facilitator, motivator, mediator, activity, and appropriateness of extension material. The motivation in business development, the use of conventional mass media by smallholder coffee farmers and the role of motivators of private extension workers for coffee farmers in Bondowoso regency were higher than in Malang regency. Factors that determined the increasing entrepreneurial capacity of smallholder coffee farmers were the level of farmer characteristics, government extension support, private extension support, and environmental support. Entrepreneurial capacity of smallholder coffee farmers was able to be strengthened through improvement of behavior and ability or determination to succeed, anticipation for future, innovative and creative, also the ability to establish cooperation with stakeholders. Smallholder coffee farmers need government extension support in the form of extension activity and fulfillment of appropriate materials. Furthermore, smallholder coffee farmers need private extension support, and environmental support in the form of nature preservation/conservation and the use of mass communication media to increase business motivation. The strengthening program can be designed in activities through non-formal education such as training, field school, and courses or workshop to accelerate entrepreneurial capacity building of smallholder coffee farmers.

\section{ACKNOWLEDGEMENT}

The authors would like to thank extension workers, students as enumerator, smallholder coffee farmers, and the Ministry of Education and Culture for providing scholarship of BPPDN Doctoral Program with No.SK 2903/D3/PG/ 2017 , hence this study was made possible.

\section{REFERENCES}

Aklimawati, L.; D. Soemarno \& S. Mawardi (2015a). Effect of service quality on coffee based economic cluster development on farmers and other stakeholders satisfaction in Bondowoso District. Pelita Perkebunan, 31, 59-72.

Aklimawati, L.; D. Soemarno \& S. Mawardi (2015b). Identification and mapping of readiness of micro and small coffee industry cluster development. Pelita Perkebunan, 31, 208-222.

Aklimawati, L. (2017). Dynamic of Arabica coffee marketing organization in Ngada District: progress upon implementing of geographical indication. Pelita Perkebunan, 33, 66-79.

Arikunto, S. (2010). Prosedur Penelitian; Suatu Pendekatan Praktek. PT Rineka Cipta, Jakarta.

BPS (2018). Statistik Kopi Indonesia. Badan Pusat Statistik Indonesia, Jakarta.

Budiningsih \& S. Watemin (2014). Pola pengembangan kewirausahaan petani pengrajin gula kelapa kristal, Jurnal Agritech, 16, 77-88.

Darmadji (2012). Analysis entrepreneurship, Jurnal Agrika, 6, 48-64.

Ditjenbun (2016). Statistik Perkebunan Indonesia; Komoditas Kopi. Direktorat Jenderal Perkebunan, Kementerian Pertanian, Jakarta, Indonesia.

Distan Bondowoso (2018). Data Produksi Perkebunan. Pemerintah Kabupaten Bondowoso, Bondowoso.

Distan Malang (2018). Data Produksi Perkebunan. Pemerintah Kabupaten Malang, Malang.

Dumasari (2014). Kewirausahaan petani dalam pengelolaan bisnis mikro di wilayah pedesaan. Jurnal Inovasi dan Kewirausahaan, 3, 192-202.

Hafif, B.; B. Prastowo \& B. Prawiradiputra (2014). Pengembangan perkebunan kopi berbasis inovasi di lahan kering masam. Jurnal Pengembangan Inovasi Pertanian, 7, 199-206. 
Hartatri, D.F.S.; S. Mawardi \& T. Wahyudi (2016). Ekonomi kopi : Produksi kopi Indonesia. p. 7-11. In: Kopi : Sejarah, Botani, Proses Produksi, Pengolahan, Produk Hilir dan Sistem Kemitraan, (Wahyudi, T., Pujiyanto \& Misnawi, Eds.). UGM Press dan Pusat Penelitian Kopi dan Kakao Indonesia, Yogyakarta.

Hawkins \& van den Ban (1999). Penyuluhan Pertanian. Kanisius, Yogyakarta.

Hisrich, R.; M. Peters \& D. Shepherd (2017). Entrepreneurship. Tenth Edition. McGraw Hill Education, New York.

Jogiyanto (2014). Pedoman Survai Kuesioner, Mengembangkan Kuesioner, Mengatasi Bias dan Meningkatkan Respon. BPFE, Yogyakarta.

Kilmanun \& J.C. Serom (2018). Peran media komunikasi dalam transfer teknologi mendukung pengembangan taman agroinovasi di Kalimantan Barat. Jurnal Pertanian Agros, 20, 134-139.

Kemen KUKM (2018). Profil Kewirausahaan Indonesia. Kementrian KUKM, Jakarta.

Leilida, J.A.; A.F. Sunartomo \& Y. Hariyati (2014). Farmer's motivation and development strategy of Arabica coffee society plantation in Sumber Wringin District Bondowoso Regency, Junal Ilmiah Pertanian, 2, 1-7.

Listiana, I.; Sumardjo; D.Sadono \& P. Tjitropranoto (2018). Affecting factors the capacity of freelance extention agents and its impacts on farmers in Lampung Province. International Journal of Business and Social Science, 9, 2219-6021.

Managanta, A.; Sumardjo; D. Sadono \& P. Tjitropranoto (2019). Factors affecting the competence of cocoa farmers in Central Sulawesi Province. Jurnal Penyuluhan, 15, 120-133.

Meredith, G.G. \&G. Geoffrey (1996). Kewirausahaan: Teori dan Praktik. Seri Manajemen. Pustaka Binaman Pressindo, Jakarta.

Meredith, G.G. \& G. Geoffrey (2000). Kewirausahaan: Teori dan Praktek. Pustaka Binaman Pressindo, New York.
Mitchelmore, S. \& J. Rowley (2013). Entrepreneurial competencies of women entrepreneurs pursuing business growth. Journal of Small Business and Enterprise Development, 1, 125-142.

Mukti, GW; R. Andriani \& P. Pardian (2018). Transformasi petani menjadi entrepreneur. Jurnal Agribisnis dan Sosial Ekonomi Pertanian, 3, 508-524.

Novanda, R. (2019). Pengaruh kelembagaan, pembiayaan, dan kemandirian terhadap kewirausahaan petani padi metode Hazton di Kabupaten Menpawah Kalimantan Barat. Journal of Agricultural Socioeconomics and Business, 2, 1-9.

Nurdiani, U. (2013). Kewirausahaan Petani dan Kinerja Usahatani Bawang Merah Di Kabupaten Bantul. Master Tesis. Fakultas Pertanian UGM, Yogyakarta.

Ningsih, D.L. (2014). Model Pengembangan Kewirausahaan Petani dan Faktor yang Mempengaruhi Adopsi Inovasi Sistem Pertanian Terintegrasi Padi Ternak Ruminansia. Master Tesis. Fakultas Ekoomi dan Manajemen, IPB. Bogor, Indonesia.

Pambudy, R. \& B. Priatna (2017). Kewirausahaan dan Manajemen Bisnis Kecil. Idemedia Pustaka Utama, Bogor.

Pratita, D.; Irham \& J. Mulyo (2018). Level kompetensi kewirausahaan petani organik di Provinsi Yogyakarta. Jurnal Agro Ekonomi, 29, 231-243.

Saragih, J.R. (2018). Aspek ekologis dan determinan produksi kopi arabika spesialti di wilayah dataran tinggi Sumatera Utara. Jurnal Wilayah dan Lingkungan, 6, 74-87.

Sugiyono (2017). Metode Penelitian Adminitrasi. Alfabeta, Bandung.

Sugiyono (2012). Metode Penelitian Kuantitatif, Kualitatif, dan $R \&$ \&. Alfabeta, Bandung.

Suryanti, R; Sumardjo; P. Tjitropranoto \& Syahyuti (2019). The role of private extension agent im broiler farmer business capacity. 
International Journal Engineering Innovative Technology and Exploring, $12,2230-2242$.

Wibowo, A.; Sumardjo; D. Hafidhuddin; S. Sarwititi \& Agung (2012). Pola komunikasi pada pengembangan kapasitas kewirausahaan petani sayuran (Kasus pendampingan misi teknik Taiwan di Kabupaten Boyolali dan Bogor). Jurnal Komunikasi Pembangunan, 10, 47-57.
Widyotomo, S; H.K. Purwadaria \& C. Ismayadi (2012). Peningkatan nilai tambah kopi melalui pengembangan proses fermentasi dan dekafeinasi. p. 135-139. In: Prosiding Seminar Insentif Riset SINas (INSINas 2012), Bandung, Indonesia.

Zizile, T. \& C. Tendai (2018). The importance of entrepreneurial competencies on the performance of women entrepreneurs. The Journal of Applied Business Research, 34, 223-236.

$* * 0 * *$ 